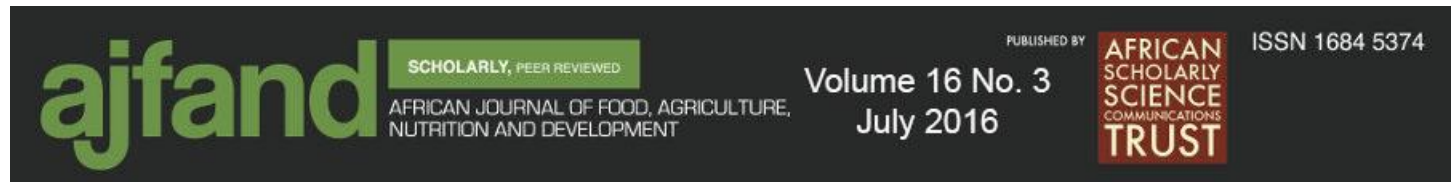

10.18697/ajfand.75.ILRI07

\title{
AFLATOXINS AND FUMONISIN CONTAMINATION OF MARKETED MAIZE, MAIZE BRAN AND MAIZE USED AS ANIMAL FEED IN NORTHERN TANZANIA
}

\author{
Nyangi C $\mathrm{C}^{1,2,4^{*}}$, Mugula JK ${ }^{2}$, Beed $\mathrm{F}^{3}$, Boni $\mathrm{S}^{4}$, Koyano $\mathrm{E}^{4}$ and M Sulyok ${ }^{5}$
}

*Corresponding author email: nyangichacha@yahoo.com

1Department of Science and Business Management, Mbeya University of Science and Technology, P.O. Box 131, Mbeya, Tanzania

${ }^{2}$ Department of Food Science and Technology, Sokoine University of Agriculture, P.O. Box 3006, Morogoro, Tanzania

${ }^{3}$ AVRDC - The World Vegetable Center, P.O. Box 1010, Kasetsart University, Bangkok 10903, Thailand

${ }^{4}$ International Institute of Tropical Agriculture, P.O. Box 34441, Dar es Salaam, Tanzania

${ }^{5}$ Department for Agrobiotechnology (IFA-Tulln), University of Natural Resources and Life Sciences (BOKU), IFA Gebäude 1, Konrad-Lorenz-Straße 20, 3430 Tulln an der Donau, Austria 


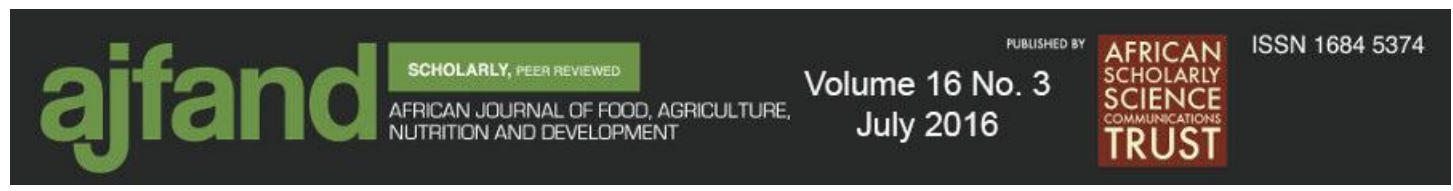

\section{ABSTRACT}

The objective of this study was to investigate the occurrence of total aflatoxin and total fumonisin in maize and maize-based products in Babati, northern Tanzania. A total of 160 samples were collected in 2013-14. Quantification for total aflatoxin and fumonisin was done using enzyme-linked immunosorbent assay (Reveal AccuScan ${ }^{\circledR}$ Neogen, USA) and the results were confirmed using Liquid Chromatography Tandem Mass Spectrometer. Aflatoxin was detected in $32 \%$ of maize samples (mean $3.4 \pm 0.3 \mu \mathrm{g} / \mathrm{kg}$; range $2.1-16.2 \mu \mathrm{g} / \mathrm{kg}$ ) and fumonisin in $39 \%$ of samples (mean $5.6 \pm 1.40 \mathrm{mg} / \mathrm{kg}$; range $0.4-62.0 \mathrm{mg} / \mathrm{kg}$ ). Among marketed products, maize bran (used for animal feed) was the most contaminated $(2.4 \mu \mathrm{g} / \mathrm{kg}$ aflatoxin and $1 \mathrm{mg} / \mathrm{kg}$ fumonisin), followed by whole maize in market stalls $(1.9 \mu \mathrm{g} / \mathrm{kg}$ aflatoxin and $0.4 \mathrm{mg} / \mathrm{kg}$ fumonisin) and then maize flour $(1.4 \mu \mathrm{g} / \mathrm{kg}$ aflatoxin and $0.3 \mathrm{mg} / \mathrm{kg}$ fumonisin). Un-marketed maize sorted out by farmers as "bad" and intended for animal feeding was the most contaminated (overall mean aflatoxin and fumonisin levels of $1.7 \mu \mathrm{g} / \mathrm{kg}$ and $7.4 \mathrm{mg} / \mathrm{kg}$, respectively). The results indicate that levels of aflatoxin and fumonisin contamination in marketed maize were within tolerable limits.

Key words: Tanzania, aflatoxins, fumonisins, food safety, maize, market, processors, animal feed 


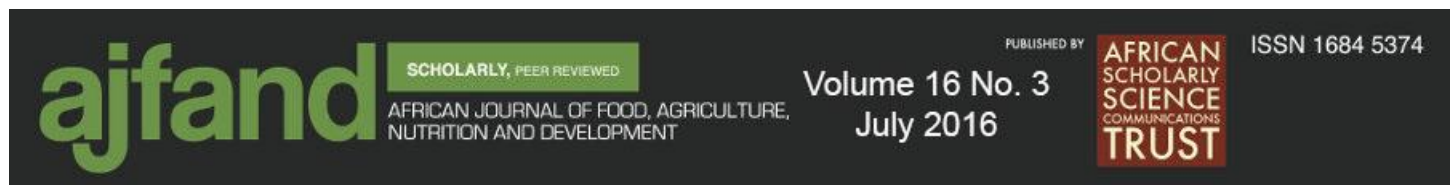

\section{INTRODUCTION}

Mycotoxins are toxic secondary metabolites produced by various fungi, many of which frequently contaminate food and feed worldwide [1]. Their prevalence depends on various factors, such as the commodity, climatic conditions, agricultural practices and storage conditions $[1,2]$. Two of the most important mycotoxigenic fungi associated with maize and other crops, fruits and nuts are Aspergillus flavus, which produces aflatoxins, and Fusarium verticillioides, which produces fumonisins [3-5].

Aflatoxin causes acute and chronic toxicity, depending on the amounts consumed. The compounds are regarded as immunosuppressive, mutagenic, teratogenic genotoxic and carcinogenic $[4,6]$. Aflatoxins seriously affect human health by inducing hepatocellular carcinoma [7]. Fumonisins have been linked to oesophageal cancer in South Africa, northern Italy and China [8-10]. Fumonisins were also associated with stunting and underweight in Tanzania [11].

Aflatoxins and fumonisins are not uniformly distributed in maize kernels and higher concentrations tend to be found in germ and bran fractions produced by dry milling due to the presence of the pericarp in these fractions. The pericarp is the first part of the kernel colonized by fungi from the environment because of its peripheral location, and also the part to which kernel dusts adhere [12]. Other studies report that during dry milling of corn, highest amounts of fumonisin B1 were found in the bran fraction used as animal feed, followed by the germ fraction, which is mainly used as animal feed and for oil extraction $[13,14]$.

Maize is a major staple food in the study sites and Tanzania as a whole. Several studies have been conducted in Tanzania on contamination of harvested, marketed and processed maize with aflatoxin and fumonisin $[11,15,16]$ and on contamination of animal products from livestock fed with contaminated feed. The aim of this study was to investigate the level of contamination along the value chain, in different types of maize available in northern Tanzania. The findings will contribute to interventions for subsistence farmers and processors to reduce aflatoxin and fumonisin contamination in the maize and maize products.

\section{MATERIALS AND METHODS}

\section{Study area}

The study was conducted in three villages (Long, Sabilo and Seloto) in Babati District, Manyara Region, northern Tanzania between August and November 2013. The villages were purposively selected in order to assess mycotoxins in different climatic zones. Villages were located in a priority research area for the United States Agency for International Development (USAID) Feed the Future initiative, where the Africa Research in Sustainable Intensification for the Next Generation (Africa RISING) eastern and southern Africa project on sustainable intensification of farming systems is being implemented. Further details are given by Nyangi et al. [17]. 


\section{Selection of vendors and processors}

The vendors and small-scale mills were selected from only two villages (Long and Seloto), as Sabilo village shared the same market and small-scale mill with Seloto village. In selected villages, five vendors were randomly selected from the village markets and 43 maize grain samples collected. Samples of maize grain $(n=29)$, maize flour $(n=24)$ and maize bran $(n=20)$ were also collected from one of the two small-scale mills in both Seloto village and Long village. Samples of maize sorted out by farmers as bad or mouldy (bad-sorted) $(\mathrm{n}=41)$ were collected from households in all three villages when farmers were about to store their maize. All participants had provided their informed consent before participating in the study.

\section{Collection of samples}

Most of the samples were collected from 100-kilogram bags of maize. Multiple samples were taken from different parts of one bag or several bags belonging to one vendor and combined to produce a one-kilogram sample for analysis, using the respective vendor's sampling tools (that is, scoops, and locally made probes commonly known in Swahili as 'bambo'). Samples were then placed in a clean A4 envelope, which was sealed, labelled and transported to the International Institute of Tropical Agriculture (IITA) plant pathology laboratory, Dar es Salaam, Tanzania. Samples were then dried in a cabinet drier at $65^{\circ} \mathrm{C}$ for 72 hours to reach less than $13 \%$ moisture content.

\section{Quantification of total aflatoxin and fumonisin}

Samples were ground using a Bunn grinder (Man: Bunn-O-Matic Corporation Springfield, Illinois, USA), homogenized and sub-divided to obtain a representative subsample for analysis. A 50-gram sub-sample was taken from each of the ground samples, extracted with $250 \mathrm{ml}$ mixture of ethanol/water $(65: 35, \mathrm{v} / \mathrm{v})$ and shaken vigorously at 150 revolutions per minute for three minutes using a laboratory shaker (IKA® Werke, Germany). Extracts were filtered through Whatman No. 1 filter paper (Whatman International Ltd. Maidstone, UK). Total aflatoxin $(\mu \mathrm{g} / \mathrm{kg})$ and fumonisin $(\mathrm{mg} / \mathrm{kg})$ were quantified following the manufacturer's protocol using Reveal AccuScan ${ }^{\circledR}$ III reader (Neogen, USA), a quantitative enzyme-linked immunosorbent assay (ELISA)-based analytical test kits designed specifically for either aflatoxin or fumonisin. The detection limit for total aflatoxin was $2 \mu \mathrm{g} / \mathrm{kg}$ with a quantitation range of $2-150 \mu \mathrm{g} / \mathrm{kg}$ and that for total fumonisin was $0.3 \mathrm{mg} / \mathrm{kg}$ with a quantitation range of $0.3-6 \mathrm{mg} / \mathrm{kg}$. The analytical quality of the ELISA methods was assured by the use of certified reference material, a naturally contaminated maize sample with a certified total aflatoxin content of $18.1 \pm 3.6 \mu \mathrm{g} / \mathrm{kg}$ and total fumonisin content of $4.2 \pm 0.6 \mathrm{mg} / \mathrm{kg}$ supplied by Neogen, USA (Neogen Corporation, USA).

For technical validation, a random subset of samples was re-analyzed using Liquid Chromatography Tandem Mass Spectrometer (LC-MS/MS) at the Interuniversity Department for Agrobiotechnology (IFA Tulln, Austria). 


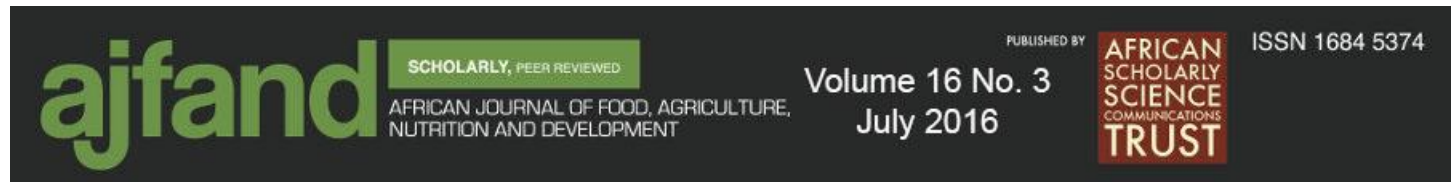

\section{Statistical analysis}

Data were analysed using Statistical Analysis System (SAS® Version 9.4, SAS Institute Incorporation, USA). The differences between means were detected using least square means to establish differences in mean total aflatoxin and fumonisin among the villages, markets and small scale-mills as well as animal feeds.

\section{RESULTS}

\section{Aflatoxins and fumonisins in maize}

All 73 samples (whole maize $=29$, bran $=20$ and flour $=24$ ) from small-scale mills had total aflatoxin and fumonisin levels below the maximum tolerable levels (MTLs) of 10 $\mu \mathrm{g} / \mathrm{kg}$ (or $10 \mathrm{ppb}$ ) and $2 \mathrm{mg} / \mathrm{kg}$ (or $2 \mathrm{ppm}$ ), respectively, set by the East African Community (EAC) [18]. They were also below the $10 \mu \mathrm{g} / \mathrm{kg}$ and $1 \mathrm{mg} / \mathrm{kg}$ standards set by the European Union [19]. Maize bran had mean fumonisin concentration of $1.0 \mathrm{mg} / \mathrm{kg}$, lower than the MTL for animal feeds of $20 \mathrm{mg} / \mathrm{kg}$ [20] (Figures 1 and 2).

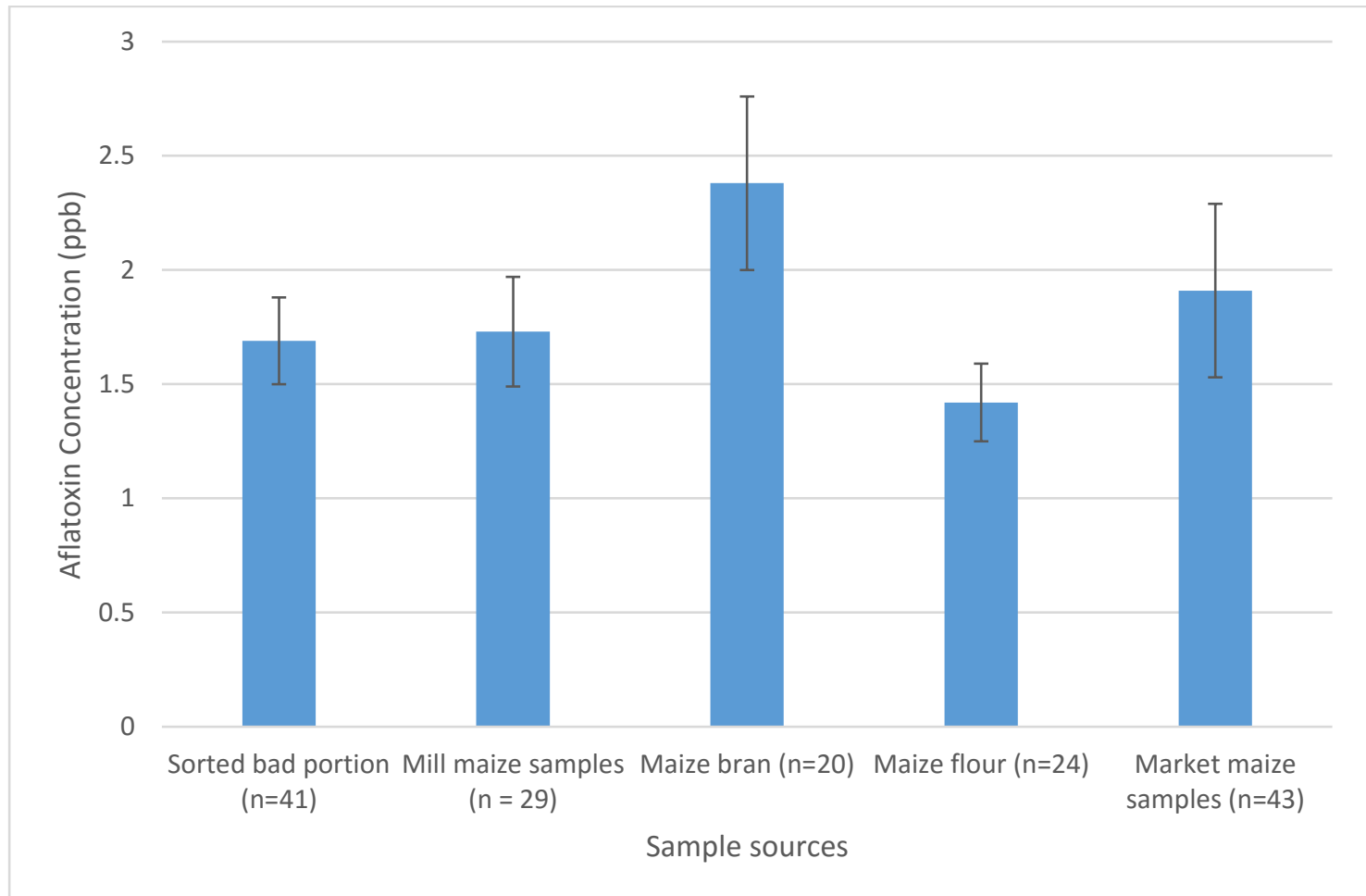

Figure 1: Mean aflatoxin levels with their corresponding standard errors 

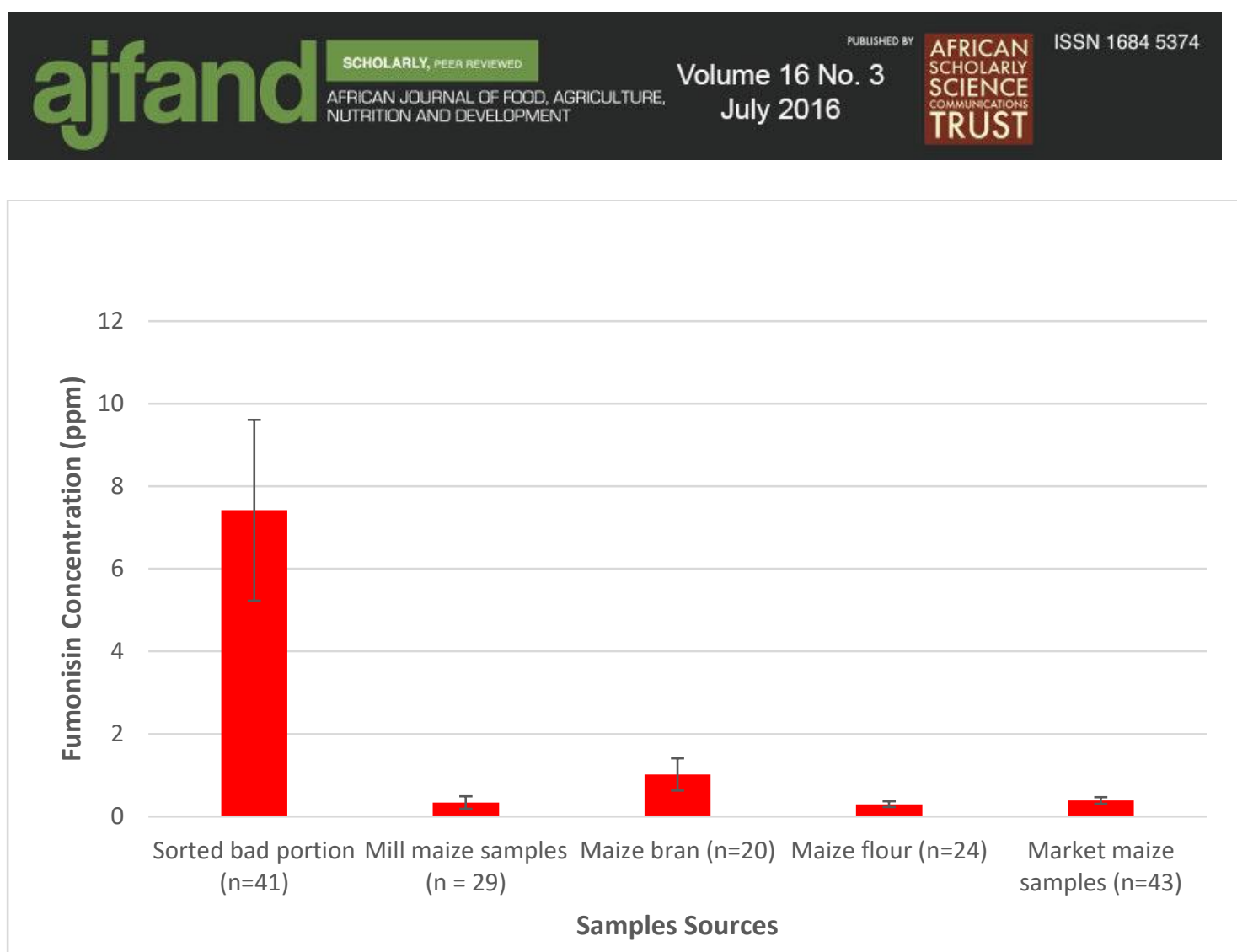

Figure 2: Mean fumonisin levels with their corresponding standard errors

Only $2 \%$ of all market maize samples had a total aflatoxin greater than the EAC and EU MTL of $10 \mu \mathrm{g} / \mathrm{kg}[18,19]$, while all samples had aflatoxin levels below the MTL of 20 $\mu \mathrm{g} / \mathrm{kg}$ by USA standards [20]. About $5 \%$ of the marketed samples had fumonisin levels above the MTL of $2 \mathrm{mg} / \mathrm{kg}$ [18]. All of the maize sorted as bad or mouldy portion collected from farmers' households and maize bran samples from small-scale mills as animal feed had contamination levels below the MTL for animal feeds of $20 \mu \mathrm{g} / \mathrm{kg}$ for aflatoxin and 5-100 mg/kg for fumonisin [21, 19] as indicated in Table 1. Differences between levels of aflatoxin and fumonisin contamination in maize and maize-based products in the three villages and their significance are shown in Tables 3 and 4 .

\section{DISCUSSION}

\section{Aflatoxin and fumonisin levels in marketed maize and maize products}

The mean value for total aflatoxin was lower than those reported in other studies [22]. In Kenya, a very high level of up to $46,400 \mu \mathrm{g} / \mathrm{kg}$ was reported, the result of prolonged drought and food shortages that were followed by off-season rains during harvest, a combination of circumstances that probably favoured the growth of aflatoxigenic Aspergillus spp. in household stored maize [7]. The mean concentration of total fumonisin was higher than a mean value of $2.9 \mathrm{mg} / \mathrm{kg}$ reported in Burkina Faso [23]. The results from the present study were also lower than those reported in Rwanda, with maximum aflatoxin and fumonisin levels of $154.9 \mu \mathrm{g} / \mathrm{kg}$ and $7.1 \mathrm{mg} / \mathrm{kg}$, respectively [5]. It was found that aflatoxin and fumonisin levels were higher in bran fractions, as expected $[12,13]$. The related study of harvested maize in the three villages found that the maize in Sabilo village had significantly higher aflatoxins and significantly lower fumonisins than the other two villages [17]. Selling maize from Sabilo in the same markets as maize 


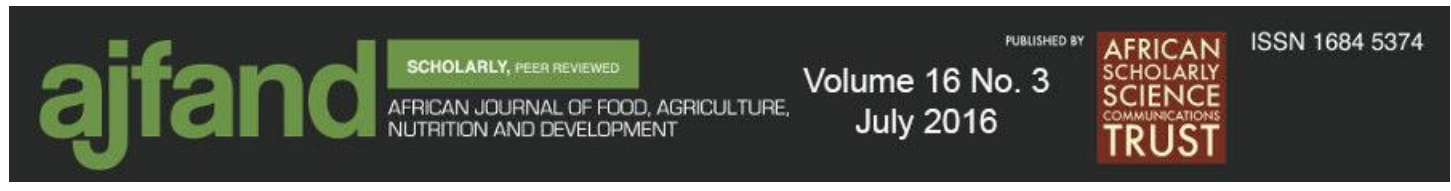

from Seloto, therefore, acts to reduce levels of aflatoxin and fumonisin compared to selling the product in separate markets, because there is a diluting effect when more contaminated maize is sold with less contaminated maize. The overall largely satisfactory results may be the effect of good agricultural practices by farmers following their participation in agricultural development programs [17].

Aflatoxin and fumonisin occurrence in non-marketed, sorted maize

The bad-sorted portion was removed from harvested maize before storage. Although aflatoxin and fumonisin levels were below the EAC MTL for animal feeds, some samples contained contamination at levels that were above the EAC MTL for human food. Levels in the bad-sorted maize were higher than reported from a study in Poland [24] and comparable to levels reported from a study in Iran [25].

\section{CONCLUSION}

The results from this study showed that most maize products consumed by humans and animals contained aflatoxin and fumonisin at levels below the EAC MTL, which is satisfactory. However, a small proportion of marketed maize was contaminated with mycotoxins at levels that exceeded EAC standards, indicating the need to improve aflatoxin and fumonisin control. Sorting out bad maize by farmers successfully mitigates fumonisin risk. Milling maize and feeding the more contaminated bran to animals also reduces human consumption of mycotoxins.

\section{ACKNOWLEDGEMENTS}

The authors thank the Innovative Agricultural Research Initiative, through the support of USAID Feed the Future, for providing a scholarship and covering part of the research cost. The authors are also grateful to IITA, through the support of the Africa RISING eastern and southern Africa project on sustainable intensification of farming systems and USAID Feed the Future, for providing technical and working facilities as well as covering part of the research cost. The authors also appreciate the support of Sylvester Temba, Lydia Munuo, Siha Koka and Samson Lyimo of Nelson Mandela African Institute of Science and Technology and Grace Michael of IITA Tanzania during the survey. 


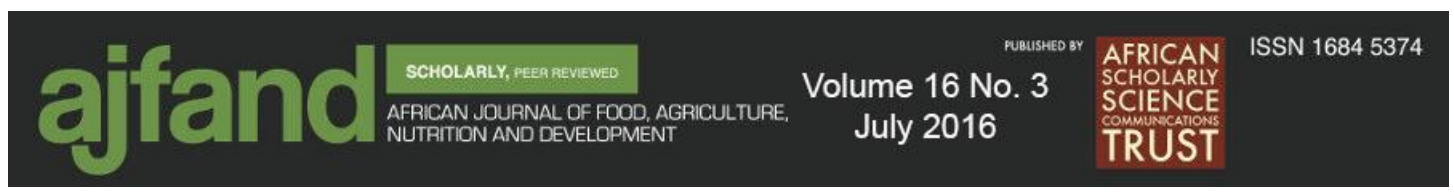

Table 1: Incidence of total aflatoxin and fumonisin contamination in maize and maize-based product samples across the three villages

\begin{tabular}{|c|c|c|c|c|c|}
\hline \multirow[t]{2}{*}{ Sample source } & \multirow[t]{2}{*}{$\mathbf{n}$} & \multicolumn{2}{|c|}{ Aflatoxin $(\mu \mathrm{g} / \mathrm{kg})$} & \multicolumn{2}{|c|}{ Fumonisin (mg/kg) } \\
\hline & & $\begin{array}{l}\text { Positive } \\
\text { sample }(\%)\end{array}$ & Mean \pm SE & $\begin{array}{l}\text { Positive } \\
\text { sample }(\%)\end{array}$ & Mean \pm SE \\
\hline Sorted bad maize & 41 & $12(29)$ & $3.49 \pm 0.28$ & $21(51)$ & $14.45 \pm 3.69$ \\
\hline Maize from mills & 29 & $10(34)$ & $3.19 \pm 0.32$ & $6(21)$ & $1.43 \pm 0.56$ \\
\hline Maize bran & 20 & $12(60)$ & $3.26 \pm 0.48$ & $12(60)$ & $1.63 \pm 0.60$ \\
\hline Maize flour & 24 & $3(13)$ & $2.97 \pm 0.12$ & $8(33)$ & $0.66 \pm 0.12$ \\
\hline Maize market & 43 & $15(35)$ & $4.00 \pm 0.91$ & $16(37)$ & $0.96 \pm 0.16$ \\
\hline
\end{tabular}

Values are means of total aflatoxin and fumonisin.

Positive samples are all analysed samples with value > limit of detection

$\mathrm{n}$ : the total number of analysed samples

SE: standard error

Maximum tolerable level of aflatoxin is $10 \mu \mathrm{g} / \mathrm{kg}$ by East Africa standards and $20 \mu \mathrm{g} / \mathrm{kg}$ by USA

standards and that of fumonisin is $2 \mathrm{mg} / \mathrm{kg}$ by East Africa standards

Maximum tolerable level of aflatoxin in animal feed is $20 \mu \mathrm{g} / \mathrm{kg}$ and that of fumonisin is $5-100 \mathrm{mg} / \mathrm{kg}$

Table 2: Overall occurrence/prevalence of aflatoxin and fumonisin in maize, and maize-based products across the three villages

\begin{tabular}{lllll}
\hline Mycotoxin & n & Positive sample (\%) & Range & Mean \pm SE \\
\hline Aflatoxin $(\mu \mathrm{g} / \mathrm{kg})$ & 160 & $51(32)$ & $2.1-16.2$ & $3.4 \pm 0.3$ \\
Fumonisin $(\mathrm{mg} / \mathrm{kg})$ & 160 & $62(39)$ & $0.4-62.0$ & $5.6 \pm 1.4$
\end{tabular}

Values are means for total aflatoxin and fumonisin levels in all analysed samples

Range is only for positive samples

Positive samples are all analysed samples with value > limit of detection

$\mathrm{n}$ : total number of all analysed samples

SE: standard error 


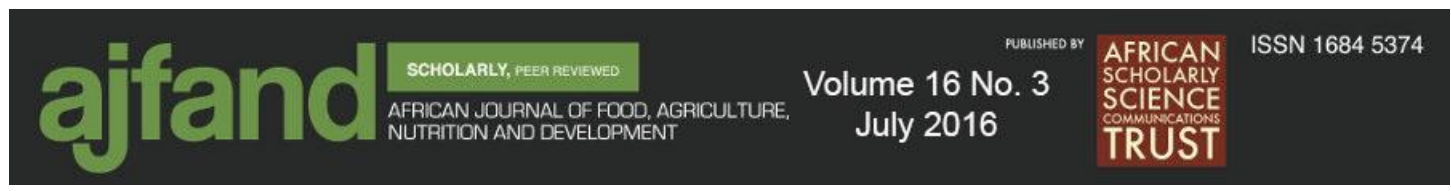

Table 3: Aflatoxin contamination in maize and maize-based products in the three villages

\begin{tabular}{|c|c|c|c|c|c|}
\hline \multirow[t]{2}{*}{ Sample type } & \multirow[t]{2}{*}{$\mathbf{n}$} & \multicolumn{4}{|c|}{ Mean aflatoxin concentration $(\mu \mathrm{g} / \mathrm{kg}) \pm \mathrm{SE}$} \\
\hline & & Mean overall* & Long village & Sabilo village & Seloto village \\
\hline Sorted bad portion & 41 & $1.7 \pm 0.2^{\mathrm{a}}$ & $1.4 \pm 0.2^{\mathrm{a}}$ & $1.9 \pm 0.4$ & $1.9 \pm 0.4^{\mathrm{a}}$ \\
\hline Maize from mills & 29 & $1.7 \pm 0.2^{\mathrm{a}}$ & $1.2 \pm 0.2^{\mathrm{ab}}$ & - & $2.7 \pm 0.4^{\mathrm{a}}$ \\
\hline Maize bran & 20 & $2.4 \pm 0.4^{\mathrm{ab}}$ & $2.2 \pm 0.3^{\text {acd }}$ & - & $2.6 \pm 0.8^{\mathrm{a}}$ \\
\hline Maize flour & 24 & $1.4 \pm 0.2^{\mathrm{ac}}$ & $1.1 \pm 0.2^{\text {abeh }}$ & - & $1.8 \pm 0.3^{\mathrm{a}}$ \\
\hline Maize from market & 43 & $1.9 \pm 0.4^{\mathrm{a}}$ & $1.5 \pm 0.2^{\text {abfhi }}$ & - & $2.5 \pm 0.8^{\mathrm{a}}$ \\
\hline
\end{tabular}

Values are means for total aflatoxin levels in all analysed samples across the three villages

Means with different letters (by column) are significantly different $(\mathrm{P}<0.05)$

$\mathrm{n}$ : total number of samples analysed

SE: standard error

* represents samples from all three villages including bad sorted portion from Sabilo village

Table 4: Fumonisin contamination in maize and maize-based products across the three villages

\begin{tabular}{|c|c|c|c|c|c|}
\hline \multirow[t]{2}{*}{ Sample type } & \multirow[t]{2}{*}{$\mathbf{n}$} & \multicolumn{4}{|c|}{ Mean fumonisin concentration $(\mathrm{mg} / \mathrm{kg}) \pm \mathrm{SE}$} \\
\hline & & $\begin{array}{l}\text { Mean } \\
\text { overall* }\end{array}$ & Long village & $\begin{array}{l}\text { Sabilo } \\
\text { village }\end{array}$ & $\begin{array}{l}\text { Seloto } \\
\text { village }\end{array}$ \\
\hline $\begin{array}{l}\text { Sorted bad } \\
\text { portion }\end{array}$ & 41 & $7.4 \pm 2.2^{\mathrm{a}}$ & $0.1 \pm 0.1^{\mathrm{a}}$ & $27.5 \pm 7.7$ & $5.2 \pm 1.1^{\mathrm{a}}$ \\
\hline Maize from mills & 29 & $0.3 \pm 0.2^{\text {ba }}$ & $0.2 \pm 0.1^{\mathrm{ac}}$ & - & $0.7 \pm 0.4^{\mathrm{bf}}$ \\
\hline Maize bran & 20 & $1.0 \pm 0.4^{\mathrm{a}}$ & $0.4 \pm 0.1^{\text {bde }}$ & - & $1.8 \pm 0.8^{\mathrm{cfg}}$ \\
\hline Maize flour & 24 & $0.3 \pm 0.1^{\mathrm{b}}$ & $0.2 \pm 0.1^{\text {acef }}$ & - & $0.5 \pm 0.1^{\mathrm{dfgi}}$ \\
\hline $\begin{array}{l}\text { Maize from } \\
\text { market }\end{array}$ & 43 & $0.4 \pm 0.1^{\mathrm{b}}$ & $0.4 \pm 0.1^{\text {bdefg }}$ & - & $0.4 \pm 0.1^{\text {efhi }}$ \\
\hline
\end{tabular}

Values are means for total fumonisin levels in all analysed samples across three villages

Means with different letters (by column) are significantly different $(\mathrm{P}<0.05)$

$\mathrm{n}$ : total number of samples analysed and (\%) for positive samples

SE: standard error

* represents samples from all three villages including bad sorted portion from Sabilo village 


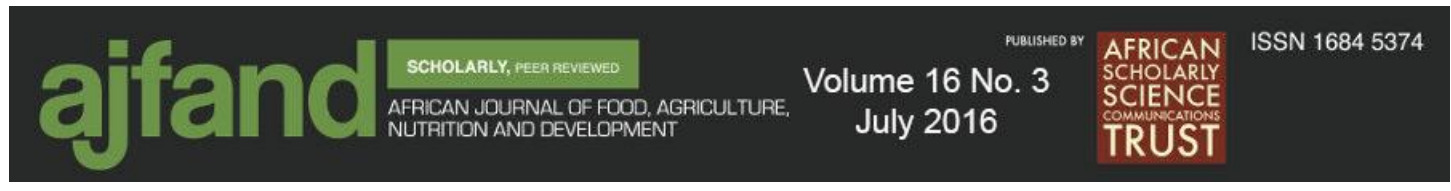

\section{REFERENCES}

1. Warth B, Parich A, Atehnkeng J, Bandyopadhyay R, Schuhmacher R, Sulyok M, and R Krska Quantitation of Mycotoxins in Food and Feed from Burkina Faso and Mozambique Using a Modern LC-MS/MS Multitoxin Method. J. Agric. Food Chem. 2012; 60(36): 9352-9363.

2. Milani JM Ecological Conditions Affecting Mycotoxin Production in Cereals: A Review. Vet. Med. (Praha) 2013; 58(8): 405-411.

3. Okoth SA and MA Kola Market Samples as a Source of Chronic Aflatoxin Exposure in Kenya. Afr. J. Health Sci. 2012; 20(1-2): 56-61.

4. Omar HEM Mycotoxins-Induced Oxidative Stress and Disease. In: Makun HA (Ed). Mycotoxin and Food Safety in Developing Countries. Rijeka, Croatia: InTech, 2013: 63-92.

5. Nyinawabali F A Survey of Fungi and Mycotoxins in Selected Food Commodities from Rwanda. University of Johannesburg, 2013.

6. Filazi A and UT Sireli Occurrence of Aflatoxins in Food. In: Razzaghi-Abyaneh M (Ed). Aflatoxins - Recent Advances and Future Prospects. Rijeka, Croatia: InTech, 2013: 143-170.

7. Lewis L, Onsongo M, Njapau H, Schurz-Rogers H, Luber G, Kieszak S, Nyamongo J, Backer L, Dahiye AM, Misore A, DeCock K, Rubin C and Kenya Aflatoxicosis Investigation Group Aflatoxin Contamination of Commercial Maize Products During an Outbreak of Acute Aflatoxicosis in Eastern And Central Kenya. Environ. Health Perspect. 2005; 113(12): 17631767.

8. Marasas WFO, Gelderblom WCA, Shephard GS and HF Vismer Mycotoxins: A Global Problem. In: Leslie JF, Bandyopadhyay R and A Visconti (Eds). Mycotoxins: Detection Methods, Management, Public Health and Agricultural Trade. 4th edition. Oxford, UK: CABI, 2008: 29-39.

9. Franceschi S, Bidoli E, Barón AE and C La Vecchia Maize and Risk of Cancers of the Oral Cavity, Pharynx, and Esophagus in Northeastern Italy. $J$. Natl. Cancer Inst. 1990; 82(17): 1407-1411.

10. Ueno Y, Iijima K, Wang SD, Sugiura Y, Sekijima M, Tanaka T, Chen C and SZ Yu Fumonisins as a Possible Contributory Risk Factor for Primary Liver Cancer: A 3-year Study of Corn Harvested in Haimen, China, by HPLC and ELISA. Food Chem. Toxicol. 1997; 35(12): 1143-1150. 


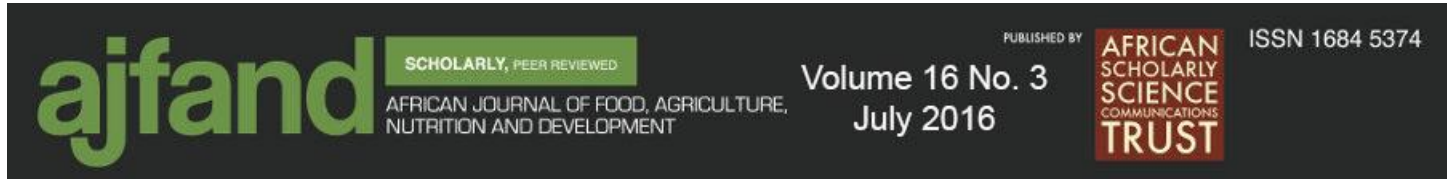

11. Kimanya ME, Meulenaer B De, Roberfroid D, Lachat $\mathbf{C}$ and $\mathbf{P}$ Kolsteren Fumonisin Exposure Through Maize in Complementary Foods is Inversely Associated with Linear Growth of Infants in Tanzania. Mol. Nutr. Food Res. 2010; 54(11): 1659-1667.

12. Brera C, Debegnach F, Grossi $\mathbf{S}$ and $\mathbf{M}$ Miraglia Effect of Industrial Processing on the Distribution of Fumonisin B1 in Dry Milling Corn Fractions. J. Food Prot. 2004; 67(6): 1261-1266.

13. Katta SK, Cagampang AE, Jackson LS and LB Bullerman Distribution of Fusarium Molds and Fumonisins in Dry-Milled Corn Fractions. Cereal Chem. 1997; 74(6): 858-863.

14. Vanara F, Reyneri A, and M Blandino Fate of Fumonisin B1 in the Processing of Whole Maize Kernels during Dry-Milling. Food Control 2009; 20(3): 235238.

15. Manjula K, Hell K, Fandohan P, Abass A and R Bandyopadhyay Aflatoxin and Fumonisin Contamination of Cassava Products and Maize Grain from Markets in Tanzania and Republic of the Congo. Toxin Rev. 2009; 28(2-3): 6369.

16. Kimanya ME, Shirima CP, Magoha H, Shewiyo DH, Meulenaer B De, Kolsteren P and YY Gong Co-exposures of Aflatoxins with Deoxynivalenol and Fumonisins from Maize Based Complementary Foods in Rombo, Northern Tanzania. Food Control 2014; 41: 76-81.

17. Nyangi C, Beed F, Mugula JK, Boni S, Koyano E, Mahuku G, Sulyok M and B Mateete Assessment of Pre-harvest Aflatoxin and Fumonisin Contamination of Maize in Babati District, Tanzania. Afr. J. Food Agric. Nutr. Dev. 2016; 16(3): 11039-11053.

18. EAC. East African Community East Africa standards: Maize grains - EAC 2/2011 [Internet]. 2011 Available from:

https://law.resource.org/pub/eac/ibr/eas.2.2011.html. Accessed April 262016.

19. The Commission of the European Communities Commission Regulation (EU) No. 165/2010 of 26 February 2010 Amending Regulation (EC) No 1881/2006 Setting Maximum Levels for Certain Contaminants in Foodstuffs As Regards Aflatoxins. Off. J. Eur. Union 2010.

20. Egmond HP van and MA Jonker Worldwide Regulations for Mycotoxins in Food and Feed in 2003: Summary of Study. FAO Food and Nutrition Paper No. 81. FAO, Rome, 2005. 


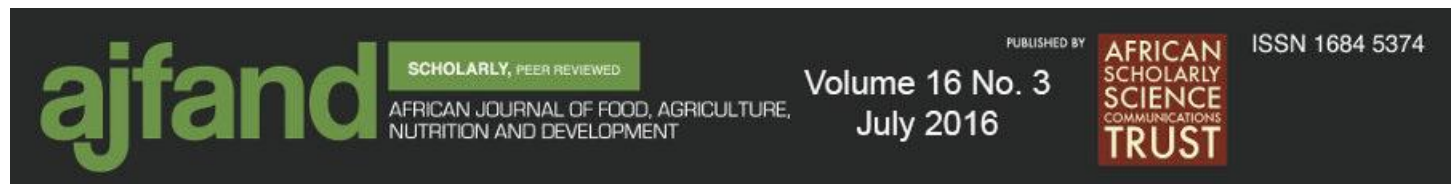

21. USFDA. Guidance for Industry: Fumonisin Levels in Human Foods and Animal Feeds; Final Guidance [Internet]. 2001 Available from: http://www.fda.gov/Food/GuidanceRegulation/GuidanceDocumentsRegulatoryI nformation/ChemicalContaminantsMetalsNaturalToxinsPesticides/ucm109231. htm. Accessed May 92016.

22. Ahsan S, Bhatti IA, Asi MR, Bhatti HN and MA Sheikh Occurrence of Aflatoxins in Maize Grains from Central Areas of Punjab, Pakistan. Int. J. Agric. Biol. 2010; 12(4): 571- 575.

23. Nikièma PN, Worrillow L, Traoré AS, Wild CP and PC Turner Fumonisin Contamination of Maize in Burkina Faso, West Africa. Food Addit. Contam. 2004; 21(9): 865-870.

24. Grajewski J, Błajet-Kosicka A, Twarużek M and R Kosicki Occurrence of Mycotoxins in Polish Animal Feed in Years 2006-2009. J. Anim. Physiol. Anim. Nutr. (Berl). 2012; 96(5): 870-877.

25. Rezaei M, Mohammadpourfard I, Malekirad AA, Ghasemikhah $\mathbf{R}$ and $M$ MehranSayadi Aflatoxin Contamination of Feed Materials in Qom Province. Iran. J. Toxicol. 2014; 8 (24): 1-4. 